\title{
ANALISIS DAN OPTIMALISASI JARINGAN NIRKABEL DENGAN MINIMALISASI ROAMING DI BINUS SQUARE
}

\author{
Audi Eka Prasetyo; Marco Stefanus; \\ Admiral Wiem; Antonius Herusutopo \\ Computer Science Department, School of Computer Science, Binus University \\ Jl. K.H. Syahdan No. 9, Palmerah, Jakarta Barat 11480 \\ ant.herusutopo@binus.ac.id
}

\begin{abstract}
The presence of a notebook/netbook that is practical and has a high mobility makes internet connection is not only done through a single cable connection. High levels of human mobility, require an internet connection with a high mobility as well, this is encouraging the development of wireless internet connection in Indonesia. The purpose of this study is to analyze the wireless network at Binus Square today and then optimize by minimizing roaming. The method of this study begins with data collection, analysis design, testing and evaluation. The method that is used is to measure bandwidth, to measure the speed and stability of data transfer when it is roaming, and then to measure the transfer speed and stability with wireless network system. From this study it can be seen that the wireless network can be a network of high-speed and stable. This study concluded that based on the simulation, this condition is quite fulfilling.
\end{abstract}

Keywords: wireless network,roaming, binus square

\begin{abstract}
ABSTRAK
Hadirnya notebook/netbook yang praktis dan memiliki mobilitas tinggi membuat koneksi internet tidak hanya dilakukan melalui koneksi kabel saja. Tingkat mobilitas manusia yang tinggi membutuhkan koneksi internet dengan mobilitas yang tinggi pula, hal ini yang mendorong perkembangan koneksi internet nirkabel di Indonesia. Tujuan penelitian ini ialah menganalisa jaringan nirkabel di Binus Square saat ini dan kemudian mengoptimalkan dengan cara meminimalkan roaming. Metode dari penelitian ini dimulai dengan pengumpulan data, analisis perancangan, uji coba dan evaluasi. Metode yang digunakan adalah mengukur bandwidth, mengukur kecepatan dan kestabilan transfer data pada saat roaming, lalu mencoba mengukur kecepatan dan kestabilan transfer dengan sistem jaringan nirkabel. Dari penelitian ini, dapat diketahui bahwa jaringan nirkabel dapat menjadi jaringan berkecepatan tinggi dan stabil. Penelitian ini menyimpulkan bahwa berdasarkan simulasi, kondisi ini cukup memenuhi.
\end{abstract}

Kata kunci: jaringan nirkabel, roaming, binus square 


\section{PENDAHULUAN}

Kemajuan teknologi yang sangat cepat dan penyebaran koneksi internet yang tersebar sangat luas di seluruh Indonesia membuat permintaan masyarakat akan koneksi internet yang cepat dan dapat diandalkan meningkat. Berawal dari maraknya internet kabel yang digunakan oleh masyarakat untuk berbagai keperluan, sehingga berbagai ISP berlomba-lomba untuk memberikan pelayanan internet cepat dan terbaik bagi pelanggannya. Hadirnya notebook/netbook yang praktis dan memiliki mobilitas tinggi membuat koneksi internet tidak hanya dilakukan melalui koneksi kabel saja. Tingkat mobilitas manusia yang tinggi membutuhkan koneksi internet dengan mobilitas yang tinggi pula, hal ini yang mendorong perkembangan koneksi internet nirkabel di Indonesia. Hampir setiap restoran, kafe, sekolah, dan tempat-tempat umum lainnya menyediakan fasilitas internet nirkabel, wi-fi, secara cumacuma untuk orang-orang yang mengunjungi tempat tersebut. Dengan alasan praktis, kini perusahaanperusahaan dan instansi-instansi menggunakan metode internet nirkabel sebagai sarana teknologi bagi mereka untuk dapat melakukan akses internet

Binus Square - Hall of Residence berfungsi sebagai tempat tinggal sementara untuk mahasiswa Binus University dan telah beroperasi sejak tahun 2010, menyediakan beberapa fasilitas yang dapat digunakan oleh boarder yang menetap di sana yang salah satu fasilitas tersebut adalah internet gratis yang menggunakan jaringan wifi. Seiring dengan pertambahan jumlah boarder sering terjadi keluhan mengenai fasilitas internet yang diberikan, keluhan itu antara lain kecepatan internet yang semakin lambat dan bisa terjadi putus koneksi secara tiba-tiba. Salah satu penyebab keluhan tersebut adalah diperkirakan terjadinya roaming. Sehingga peneliti mencoba meminimalisasi roaming agar jaringan nirkabel di Binus Square lebih optimal. Hasil penelitian ini diharapkan dapat digunakan di lokasi-lokasi/instansi lain yang menggunakan wireless LAN dan mengalami masalah yang sama dengan yang ada di Binus Square.

\section{METODE}

Metode yang digunakan meliputi metode pengumpulan data, analisa, identifikasi masalah, dan perancangan atau implementasi sistem. Metode pengumpulan data meliputi studi literatur mengenai teori jaringan nirkabel dan teori roaming dan mengukur bandwidth menggunakan aplikasi alat ukur jaringan pada sistem nirkabel yang sudah berjalan di Binus Square agar diketahui bandwidth yang ada apakah sudah mencukupi atau kurang memadai. Selanjutnya akan dilakukan pengukuran kecepatan transfer data pada saat roaming kemudian dilihat kestablilan transfer data pada saat terjadi roaming dan observasi jangka panjang agar dapat diketahui waktu pada saat terjadi koneksi yang kurang stabil dan penyebabnya. Data yang diperoleh akan disimpan dan didokumentasikan untuk dijadikan dasar penentuan solusi terbaik yang dapat diterapkan dalam sistem jaringan nirkabel Binus Square agar koneksi jaringan nirkabel stabil dan optimal. Selanjutnya, akan dilakukan implementasi perubahan sistem jaringan nirkabel dan diharapkan dapat menyelesaikan masalah yang ada pada sistem jaringan nirkabel Binus Square.

\section{Bandwidth}

Menurut Mitchell (2011), Bandwidth adalah besaran yang menunjukkan seberapa banyak data yang dapat dialirkan dalam koneksi melalui sebuah network. Lebar pita atau kapasitas saluran informasi adalah kemampuan maksimum dari suatu alat untuk menyalurkan informasi dalam satuan waktu detik. Dikenal juga dengan perbedaan atau interval, antara batas teratas dan terbawah dari suatu frekuensi gelombang transmisi dalam suatu kanal komunikasi. Satuan yang digunakan dalam pengukuran di sini adalah Hertz atau sikel per detik (cycle per second). 
Jalur lebar analog diukur dalam unit Hertz (Hz) atau sikel per detik (cycle per second). Jalur lebar digital juga merujuk kepada jumlah atau volume data yang dialirkan melalui satu saluran komunikasi yang diukur dalam unit bit per second (bps) tanpa melibatkan gangguan. Istilah lebar jalur (bandwith) selayaknya tidak dicampur adukkan dengan istilah jalur (band), contohnya seperti pada telepon tanpa kabel, beroperasi pada jalur $800 \mathrm{MHz}$. Lebar jalur ialah ruang yang digunakan pada jalur tersebut. Dalam komunikasi tanpa kabel (wireless), ukuran atau lebar jalur salurannya sangat bagus dibanding saluran transmisi lainnya. Sejumlah data yang mengalir melalui satu saluran sempit mengambil waktu yang lebih lama dibandingkan dengan sejumlah data yang sama apabila mengalir melalui satu saluran yang lebih lebar.

Pada standarisasi 802.11b, komunikasi wireless menggunakan frekuensi 2,4 GHz. Spektrum frekuensi tersebut dibagi menjadi beberapa kanal. Kanal tersebut memiliki rentang $22 \mathrm{MHz}$ dengan selisih $5 \mathrm{MHz}$. Terdapat overlap pada kanal yang berdekatan dan dapat terjadi saling interferensi.

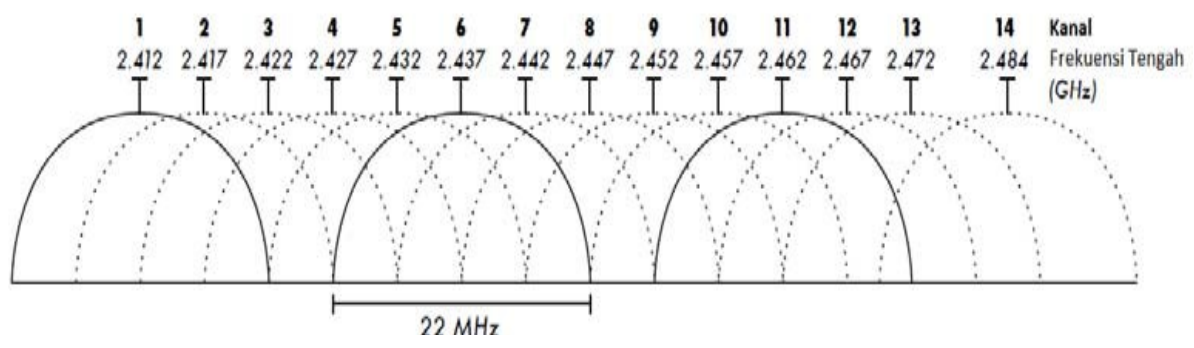

Gambar 1 Kanal frekuensi2,4GHz

\section{Jaringan Wireless 802.11}

Pada jaringan wireless, alat yang saling berkomunikasi harus berada pada spektrum frekuensi yang sama. 802.11a menggunakan frekuensi $5.0 \mathrm{GHz}, 802.11 \mathrm{~b}$ pada frekuensi sekitar 2.4 GHz.Selain pada spectrum frekuensi yang sama, alat yang berkomunikasi juga harus berada pada kanal yang sama.

Terdapat 4 mode yang dapat difungsikan pada alat yang mendukung 802.11a,802.11b/g, yaitu: (1) Mode master (mode AP atau mode infrastruktur). Dalam penggunaan pada umumnya berfungsi seperti akses poin. Network Interface Card membentuk jaringan dengan nama khusus yang disebut dengan SSID, kanal khusus dan melayani koneksi antar alat. (2) Mode managed (mode user). Network Interface Card dalam mode ini akan bergabung dengan jaringan master dan otomatis menyesuaikan kanal. (3) Mode ad-hoc. Pembentukan jaringan multipoint-to-multipoint, sehingga tidak ada istilah master, di mana dalam mode ini setiap alat akan berkomunikasi secara langsung tanpa perantara. (4) Mode monitor. Dalam penggunaan pada sejumlah alat biasanya untuk mendengar trafik secara pasif, tidak ada data yang dapat dikirim pada mode ini.

Pada jaringan nirkabel ada empat komponen penting dalam komunikasi wireless yaitu mobile station, access point (AP), media transmisi, dan sistem distribusi. Berikut komponen wireless berdasarkan IEEE 802.11: (1) Stations (user) adalah perangkat komputer dengan wireless network interfaces. Biasanya merupakan alat dengan power bateray seperti laptop, dan komputer jinjing, tapi bisa juga merupakan sebuah workstation. (2) Access points (AP) merupakan alat yang menjembatani antara jaringan wireless dan kabel. (3) Distribution system (DS) merupakan mekanisme pertukaran frame antara AP dengan user melalui jaringan kabel. Biasanya DS merupakan jaringan Ethernet yang digunakan sebagai backbone. (4) Media wireless adalah medium transmisi sinyal yaitu udara lewat peralatan tertentu. 


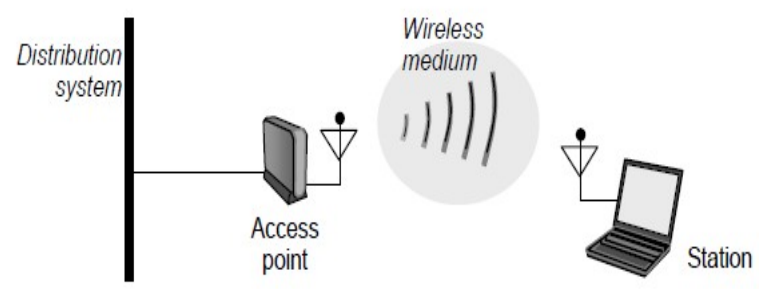

Gambar 2 Komponen nirkabel

\section{Roaming (802.11f) dan analisa wireless}

Dalam waktu dekat ini, vendor WLAN menuju ke suatu perubahan, menawarkan metodemetodenya untuk mengatasi roaming di antara masing-masing node. Software third party (software yang disediakan oleh pihak lain selain vendor WLAN) yang langsung pakai sudah tersedia untuk digunakan pada cache yang mewakili node-node yang roaming pada layer TCP/IP, ketika node tidak dikenali oleh mesin penganalisa paket.

802.11f merupakan standar yang dikeluarkan IEEE agar setiap vendor akses poin dapat mendukung fitur roaming. Dengan fitur ini user dapat berpindah koneksi dari akses poin ke akses poin (AP) lain tanpa terputus. Dalam 802.11f, user akan melakukan re-associated dengan AP baru bukan melakukan associated ulang dengan AP baru. AP juga melakukan pemantauan terhadap user, dan saling berkomunikasi antar AP melalui DS (Ethernet LAN). Pada kenyataannya tidak semua station bertindak sesuai standar, beberapa tidak pernah melakukan reassociate namun melakukan associate ulang, sehingga roaming dapat mengganggu koneksi station.

\section{Karakteristik dan Sifat Roaming}

Roaming terdiri dari dua macam karakterisitik yaitu: (1) Seamless Roaming - adalah kondisi di mana roaming terjadi pada saat transfer data sedang berjalan, dan roaming yang terjadi tidak mengakitbatkan transfer data yang sedang berlangsung terputus. (2) Nomadic Roaming - adalah roaming yang terjadi saat tidak ada transfer data pada client.

Roaming dalam 802.11 memiliki suatu sifat yang sama yaitu "break before make". Yang dimaksud dengan "break before make" adalah sebuah client yang memutuskan koneksi dengan sebuah access point sebelum melakukan koneksi ke access point yang baru. Mungkin tampak tidak menguntungkan dari sisi client, tapi dengan sifat roaming ini, bisa menyajikan protocol MAC yang lebih sederhana.

\section{Roaming Domain}

\section{Layer 2 Roaming}

Ada beberapa alasan yang harus ada untuk mendukung terjadinya roaming, yaitu: (1) Client harus memutuskan untuk melakukan roaming. Alasan roaming terjadi itu bergantung sepenuhnya pada algoritma yang dibuat oleh vendor hardware dan juga didasarkan oleh beberapa faktor lain seperti kekuatan sinyal, frame acknowledgment, missing beacons, dan lain-lain. (2) Client harus memutuskan untuk melakukan roaming ke AP yang mana. AP yang dipilih untuk melakukan roaming dapat ditentukan sebelum melakukan roaming (yang disebut dengan preemptive AP discovery), atau AP dipilih setelah melakukan roaming (yang disebut dengan roam-time AP discovery). 


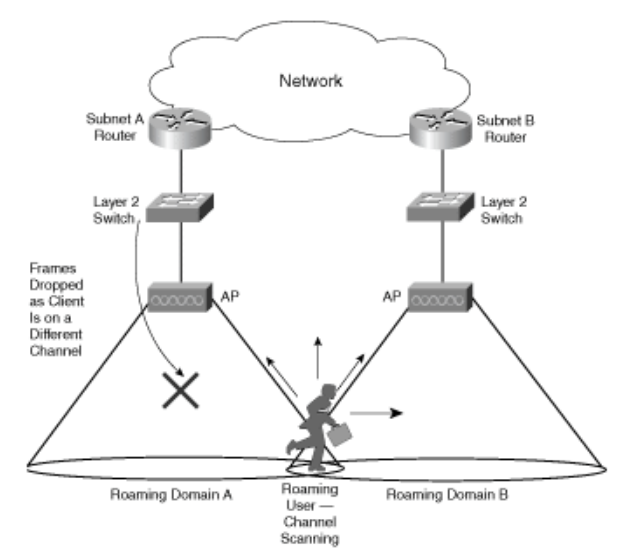

Gambar 3 Preemptive AP Discovery

Gambar 3 menunjukkan bagaimana preemptive AP discovery terjadi dalam sebuah jaringan. Untuk menentukan AP mana yang akan di-roaming, client akan melakukan scanning pada saat tidak terjadi roaming. Tapi terdapat kekurangan dalam preemptive AP discovery ini, yaitu ketika client melakukan scanning AP, client tidak bisa menerima data masuk karena client melakukan scanning dengan berpindah channel dalam jaringan. Begitu juga data dari client keluar juga tidak bisa dilakukan dalam preemptive AP discover. Oleh karena itu perlu dilakukan retransmission data ketika client melakukan scanning.

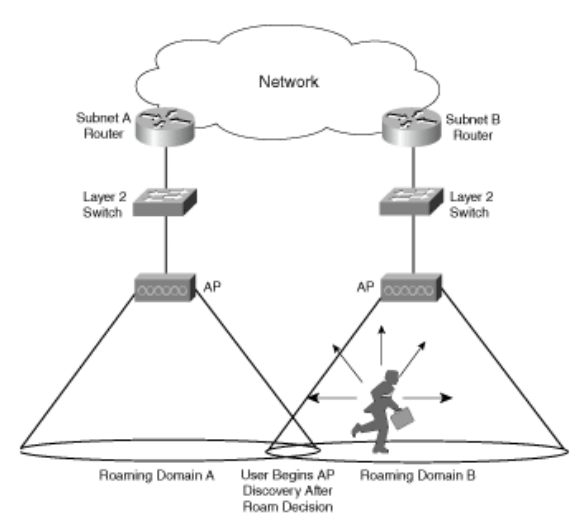

Gambar 4 Roam-Time AP Discovery

Gambar 4 di atas menunjukkan bagaimana roam-time AP discovery terjadi. Data yang dikirim dari client ke AP yang baru mengandung frame association. Karena client melakukan roaming terlebih dahulu sebelum mendapatkan AP yang tepat, kemungkinan besar akan terjadi delay waktu yang lumayan lama karena client harus mencari AP yang baru.

Proses roaming bukan hanya cuma mencari AP baru, ada beberapa hal lain yang terjadi di layer 2, yaitu: (1) AP yang sebelumnya harus memutuskan bahwa client sudah berpindah ke AP lain. (2) AP yang sebelumnya harus meng-buffer data yang ditujukan ke client. (3) AP baru harus memberitahukan ke AP lama bahwa client sudah berpindah ke AP baru (biasanya melalui unicast atau multicast packet dari AP lama ke AP baru). (4) AP yang sebelumnya harus mengirim data yang telah di-buffer ke AP baru. (5) AP harus memperbaharui MAC address tablesdi switch pada infrastruktur untuk mencegah kehilangan data dari client yang melakukan roaming. 
Dibawah ini terdapat gambaran bagaimana proses terjadinya roaming:

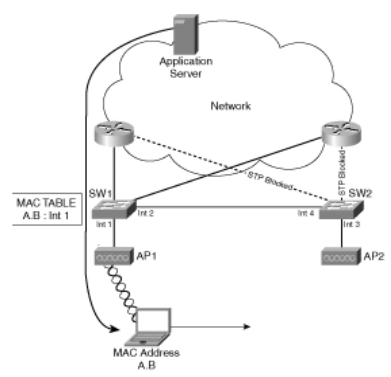

Gambar 5 Proses roaming

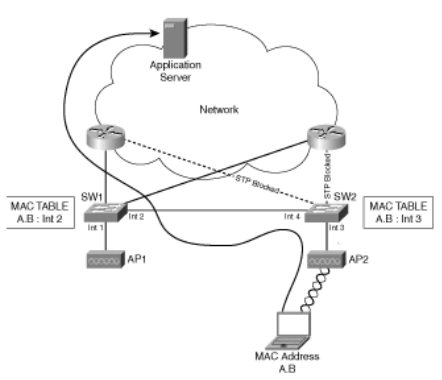

Gambar 7 Client roaming

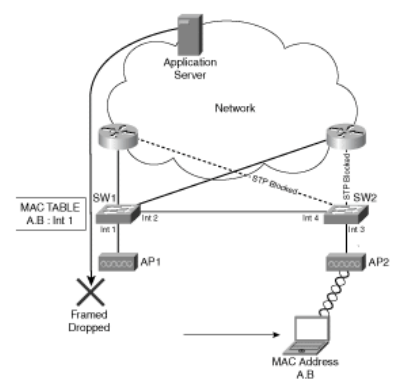

Gambar 6 Server kirim data

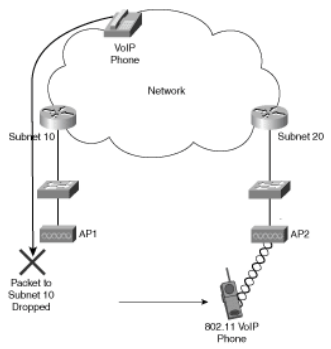

Gambar 8 Perbaikan situasi

Pada Gambar 6, application server mengirimkan data ke client dengan MAC address A.B ke SW1 via int1. SW1 mengecek forwarding table dan mengirimkan frame ke AP1. Pada Gambar 7, client telah melakukan roaming ke AP2, tapi AP1 tidak tahu bahwa client telah melakukan roaming ke AP2, maka paket di-drop karena client tidak terhubung dengan AP1 lagi. Gambar 8 menunjukkan AP2 memperbaiki situasi ini dengan mengirimkan paket ke AP1 yang berisi source MAC address yang telah diganti ke MAC address A.B. SW2 melakukan update di forwarding table-nya karena telah menerima MAC address baru di port int3. MAC address dari A.B kemudian ditambahkan ke forwarding table-nya SW2 dan di map ke int3. Frame tersebut kemudian di-forward ke SW1, untuk kemudian SW1 mengubah forwarding table-nya agar paket menuju client dapat dikirim melalui SW2.

\section{Layer 3 Roaming}

Client harus melakukan layer 2 roaming terlebih dahulu baru bisa memulai layer 3 roaming. Gambar di atas menunjukkan bagaimana roaming antar domain terjadi dalam kasus 802.11 Voip phone. Ketika Voip phone berpindah AP2 di subnet 20, terjadi pemutusan panggilan. Untuk mencegah terputusnya koneksi saat terjadinya roaming antar VLAN, dibutuhkan suatu mekanisme untuk tetap menggunakan layer 3 address yang sama walaupun telah melakukan roaming antar VLAN. Mobile IP menyediakan mekanisme yang dapat digunakan oleh semua vendor sebagai solusi di layer 3 roaming pada jaringan nirkabel.

Mobile IP memiliki beberapa komponen utama: (1) Mobile Node (MN): client yang melakukan roaming. (2) Home Agent (HA): HA terdapat pada router atau layer 3 switch dan memastikan sebuah client (MN) yang melakukan roaming tetap menerima paketnya. (3) Foreign Agent (FA): FA terdapat pada layer 3 switch dan membantu MN untuk memberitahukan kepada HA lokasi MN yang baru dengan menerima paket dari HA yang ditujukan ke MN. (4) Care-of address (CoA): CoA adalah router yang terpasang di jaringan bertugas untuk menerima paket yang ditujukan 
ke MN dari HA. (5) Co-located Care-of address (CCoA): CCoA adalah CoA yang terdapat di dalam Mobile Node (MN) itu sendiri.

Roaming dengan menggunakan mekanisme Mobile IP ada beberapa tahap, yaitu: (1) Client berada dalam Home subnet apabila IP client termasuk dalam range subnet dari HA. (2) Setelah MN (client) melakukan roaming ke subnet lain, MN mendeteksi kehadiran FA yang berada di layer 3 switch pada subnet baru dan mendaftar ke FA atau melalui CCoA yang terdapat pada MN. (3) FA atau MN CCoA melakukan komunikasi dengan HA dan menciptkan tunnel diantara HA dan CoA untuk MN. Tunneling yang dimaksud adalah mengenkapsulasi paket dengan IP header yang lain agar dapat dikirimkan ke tujuan jaringan yang lain (bahkan yang tidak terhubung langsung). Gambar dibawah menjelaskan enkapsulasi yang terjadi. Tunneling membutuhkan entry point dan exit point. Entry point mengenkapsulasi paket dengan IP header lain agar dapat dikirimkan ke tujuan jaringan lain. Di exit point, enkapsulasi tersebut dihilangkan dan di-forward ke MN. (4) Paket yang ditujukan untuk MN dikirim ke HA (melalui IP routing normal). HA mengirimkan paket ke MN melalui tunnel yang dibuat di tahap ketiga. (5) Paket apapun yang dikirimkan oleh MN, dikirim melalui FA seperti yang terjadi pada jaringan lokal (melalui reverse tunneling). Lihat gambar dibawah untuk keterangan lebih jelas.

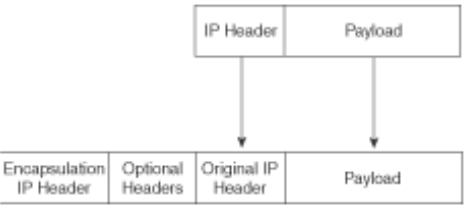

Gambar 9 Enkapsulasi

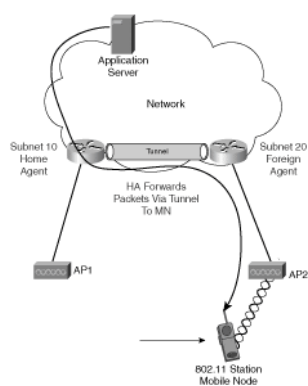

Gambar 10 Pengiriman paket IP routing normal

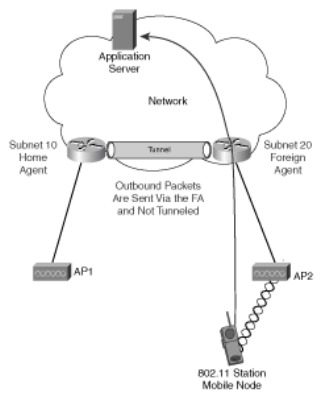

Gambar 11 Pengiriman paket melalui reverse tunelling

\section{Faktor penting dalam implementasi jaringan nirkabel}

Beberapa faktor penting yang harus diperhatikan dalam implementasi jaringan nirkabel antara lain: (1) Frekuensi - Tidak banyak frekuensi kosong yang dapat digunakan untuk frekuensi radio jaringan nirkabel. Oleh karena itu beberapa hal yang perlu diperhatikan dalam implementasi jaringan nirkabel yaitu menjaga jarak antar sistem atau membatasi area cakupan suatu sistem, serta memperkecil daya pancar yang digunakan. (2) Interferensi - Jika beberapa jaringan nirkabel digunakan dalam satu gedung maka interferensi merupakan hal penting yang perlu dicegah. Hal ini biasanya terjadi pada gedung bertingkat yang terdiri dari beberapa kantor atau perusahaan yang masing-masing memiliki sistem nirkabel data sendiri. Sistem nirkabel data perlu didesain agar dapat 
menggunakan spektrum frekuensi secara bersama. Tentu hal ini membutuhkan perencanaan frekuensi yang cukup rumit.

\section{Teknologi Beamflex}

Beamflex merupakan teknologi yang terdapat pada akses poin Ruckus Wireless, Zone Flex yang dikenal dengan teknologi smart antenna array. Akses poin Ruckus dapat mengatur pola radiasi antena berbeda dengan teknologi antena omni yang memancarkan sinyal ke segala arah, Beamflex dapat mengatur pola pemancaran dengan jalur yang terbaik ke arah penerima. Begitu juga perbedaan terdapat dengan antena direksional, Beamflex dapat mengatur pola pemancaran secara dinamis untuk menghasilkan sinyal yang lebih baik sehingga dengan teknologi Beamflex akan didapat kekuatan sinyal yang maksimal. Melalui pernyataan dari Skill ICT Solution maka dapat disimpulkan keuntungan-keuntungan yang ditawarkan teknologi Beamflex, yaitu sebagai berikut: (1) Penambahan performa dan jarak. (2) Cakupan yang lebih luas. (3) Performa jaringan nirkabel yang stabil. (4) Efisiensi maksimal power. (5) Interferensi lebih kecil.

Gambar berikut memperlihatkan perbedaan pola pemancaran sinyal akses poin dengan teknologi Beamflex dan tanpa teknologi Beamflex (Priscaro, M. 2010):

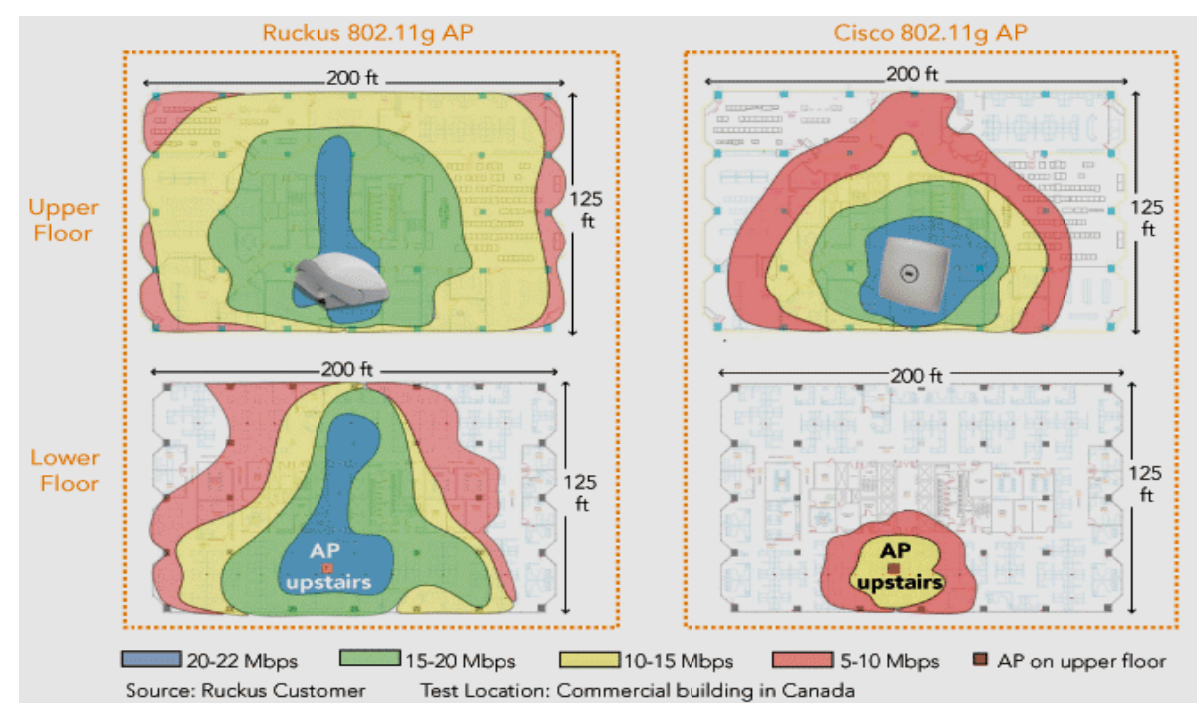

Gambar 12 pola pemancaran sinyal akses poin dengan teknologi beamflex (kiri) dan tanpa Beamflex (kanan)

\section{Ruckus Zoneflex}

Zoneflex adalah salah satu produk akses poin nirkabel dari Ruckus yang menggunakan teknologi Beamflex. Zoneflex dapat digunakan sendiri atau digunakan untuk membentuk suatu sistem terpusat yang diatur oleh Zone Director dari Ruckus (Priscaro, M. 2010). Menurut Ruckus Wireless ada beberapa keunggulan yang dapat dihasilkan akses poin nirkabel Zonefles yaitu sebagai berikut: (1) Teknologi beamflex yang menghasilkan jarak yang lebih jauh dan cakupan yang lebih luas. (2) Pemilihan channel prediktif secara real-time, Channel Fly, yang merupakan pendekatan paling efektif dalam pemilihan channel yang menghasilkan performa lebih baik sebesar 50\%. (3) Pemilihan jalur sinyal yang paling optimal, interferensi lebih kecil, dan auto manajemen frekuensi radio. (4) Smart mesh networking yang mengurangi biaya besar yang diperlukan dalam menarik kabel ethernet ke akses poin. (5) Keamanan yang baik dengan dynamic pre-shared key, enkripsi serta mekanisme 
autentikasi terbaru. (6) Cakupan lebih baik dengan akses poin lebih sedikit. (7) Mengatur semua traffic dan request/response antara klien nirkabel.

\section{Ruckus Zone Director}

Ruckus Zone Director digunakan dalam suatu sistem terpusat untuk mengontrol semua akses poin Ruckus Zoneflex. Zone Director dapat menyediakan manajemen jaringan nirkabel yang luas, keamanan, frekuensi radio, dan lokasi (Priscaro, M. 2010). Zone Director dan Zoneflex yang diimplementasi secara bersama dapat menghasilkan smart mesh network, sehingga cakupan sinyal yang diperoleh lebih luas meskipun tidak keseluruhan akses poin terhubung dengan jaringan ethernet. Akses poin membentuk topologi jaringan mesh dan melakukan routing trafik antar akses poin dan jaringan ethernet ke user. Fitur lain yang terdapat pada Ruckus Zone Director adalah deteksi rogue akses poin dan dapat mencatat user tidak baik (malicious user). Saat ada akses poin yang berdekatan maka Zone Director secara otomatis akan mengatur kanal frekuensi tiap akses poin untuk mendapatkan cakupan sinyal yang paling baik.

\section{Syslog}

Syslog menurut Kotz (2006) adalah standar yang ditentukan untuk mengirim dan menerima pesan, yang dapat disimpan secara lokal maupun dikirimkan melalui jaringan ke host lain. Tidak ada format standar untuk pesan syslog, informasi yang dikirim dapat memiliki format dan informasi yang bervariasi tergantung akses poin. Dalam Zone Director terdapat fitur syslog di mana Zone Director mencatat pesan syslog yang diterima dari setiap akses poin yang diatur melalui Zone Director tersebut di mana dalam syslog terdapat informasi host-host yang terhubung maupun terputus ke dan dari akses poin juga ada informasi roam dari dan roam ke tiap device yang terhubung dengan akses poin.

\section{Ekahau Heatmapper}

Ekahau heatmapper adalah sebuah aplikasi yang berfungsi untuk melihat jangkauan sinyal wireless dalam peta yang telah disediakan sebelumnya. Jadi aplikasi ini dapat melokasikan semua akses poin yang dapat ditangkap device dan melacak jangkauan sinyal yang dimiliki tiap akses poin begitu juga dengan informasi akses poin dan channel yang telah dikonfigurasi pada akses poin tersebut. Aplikasi ini juga dapat melihat konfigurasi keamanan dalam akses poin dan melihat jaringan yang terbuka. Jangkauan sinyal melalui akses poin dapat terlihat dengan warna sinyal mulai dari biru muda yang paling baik sampai dengan warna merah yang menandakan sinyal yang buruk.

Keterangan warna sinyal: biru muda -0 - -35 dBm; hijau tua -36 - -60 dBm; hijau biasa: -61 - $75 \mathrm{dBm}$; hijau muda -76 - -80 dBm; kuning -81 - -90 dBm; oranye -91 - -95 dBm; merah -96 - -100 $\mathrm{dBm}$.

Keterangan kekuatan sinyal: $-0 \mathrm{dBm}--60 \mathrm{dBm}$ jangkauan sinyal yang baik sampai sangat baik; $-60 \mathrm{dBm}$ - -80 dBm masih dapat terhubung, tetapi tidak dengan kecepatan maksimal; -80 dBm - -100 dBm koneksi tidak stabil, sering terputus, kecepatan lambat, dan isu performa dengan streaming video maupun audio.

\section{HASIL DAN PEMBAHASAN}

Gambar dibawah ini menunjukkan sistem yang sedang berjalan di Binus Square, di mana dalam Binus Square terdapat jaringan wired dan wireless LAN. Jaringan wired LAN terdapat beberapa server seperti Opera, proxy, dan radius server yang digunakan untuk mendukung berbagai kebutuhan Binus Square. Opera server digunakan untuk pelayanan reservasi tamu pada Binus Square hotel dan boarder seperti billing. Proxy server digunakan sebagai cache data internet untuk mengurangi beban dari bandwidth eksternal Binus Square. Radius server digunakan untuk autentikasi semua pengguna 
jaringan nirkabel Binus Square, dalam hal ini merupakan semua boarder Binus Square. Sedangkan jaringan kabel Binus Square dipergunakan untuk kebutuhan staff yang bekerja di Binus Square, kebutuhan boarder untuk belajar pada reading room, maupun penggunaan CCTV pada setiap lantai tiap tower Binus Square dan area-area publik seperti reading room, tiap pintu masuk, gym, games room maupun di area outdoor Binus Square. Saat ini terdapat 36 komputer (27 buah komputer karyawan dan 9 buah komputer reading room) yang dapat menggunakan jaringan kabel Binus Square. Gambar dibawah menunjukkan topologi jaringan layer 3 yang terdapat di Binus Square.

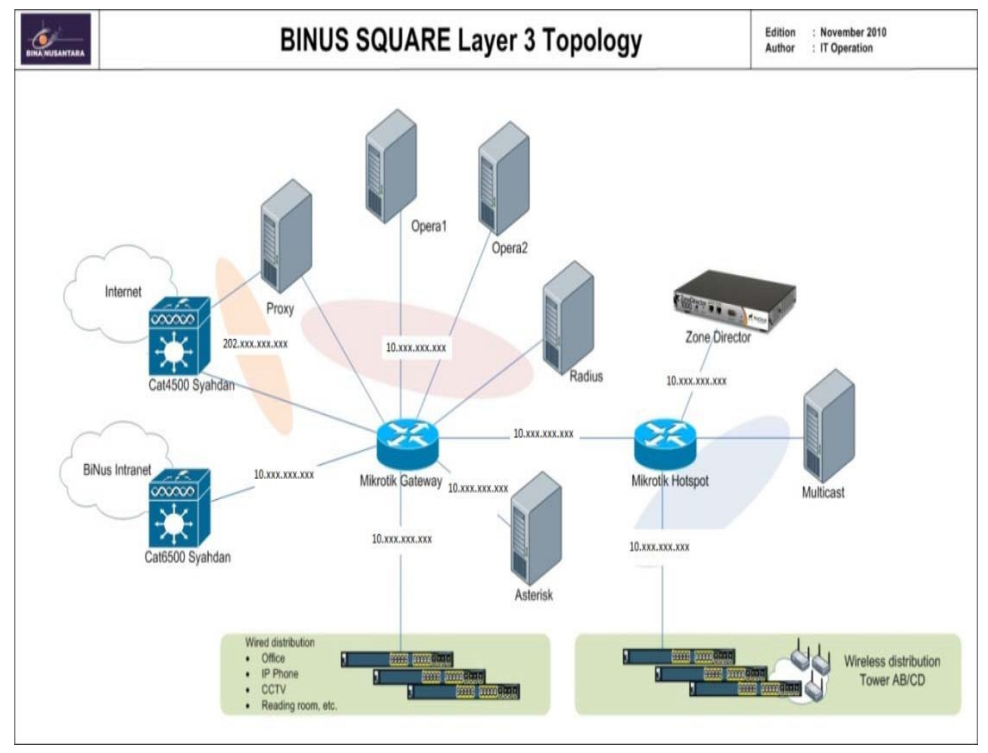

Gambar 13 Topologi layer 3 jaringan Binus Square

Gambar 13 menunjukkan topologi distribusi jaringan nirkabel LAN di Binus Square. Pada jaringan Binus Square terdapat 1 mikrotik gateway, 1 mikrotik hotspot (router), 22 manageable Ethernet switch, dan sebuah wireless controller. Koneksi internet Binus Square diambil melalui jaringan kampus Binus Syahdan dengan media kabel fiber optik dan didistribusikan melalui mikrotik gateway dan mikrotik hotspot. Jaringan kemudian didistribusikan ke tower AB dan CD melalui dua buah manageable switch distribution Tower AB dan CD. Dari switch distribution Tower AB dan CD kemudian disebar melalui 12 manageable switch per lantai. Kemudian dari switch per lantai jaringan kemudian didistribusikan ke user dengan menggunakan akses poin (AP). Pada saat ini di Binus Square terdapat 163 akses poin yang dapat digunakan untuk internet baik oleh publik maupun boarder Binus Square, tetapi karena objek yang khusus diteliti merupakan tower A dan B saja yang merupakan tower pria maka akses poin yang termasuk dalam penelitian berjumlah 90 buah. Pertama kali SSID jaringan Binus Square hanya menggunakan 1 SSID yaitu Boarder@Binus Square yang dipakai oleh semua user pada lantai 2 sampai 18, hal ini menyebabkan seringnya terjadi roaming pada jaringan Binus Square karena user tidak sadar apabila mereka sudah berpindah akses poin. Perubahan SSID lalu dilakukan dan sekarang SSID dibagi berdasarkan lantai menurut tower pria dan wanita. Berdasarkan SSIDnya, jaringan nirkabel di Binus Square dapat dibagi menjadi Public dan SSID tiap lantai di setiap tower Binus Square. 


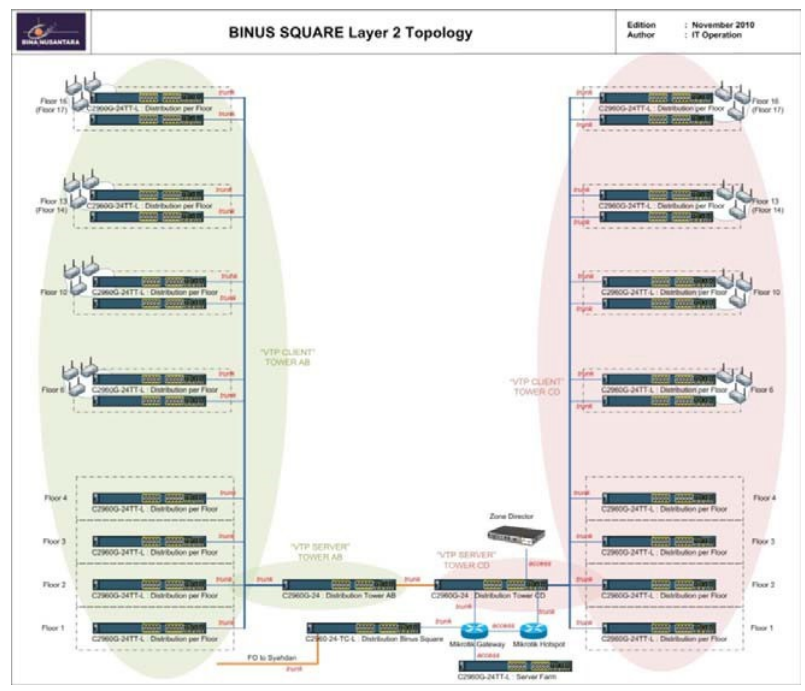

Gambar 14 Topologi layer 2 jaringan Binus Square

WVLAN yang sedang berjalan di Binus Square dibagi per tower, di mana terdapat empat tower di Binus Square sehingga WVLAN berjumlah empat buah yang dikonfigurasi di sistem jarigan Binus Square. Di bawah ini tabel pembagian WVLAN yang sedang berjalan di Binus Square.

Tabel 1 Pengaturan WVLAN di Binus Square

\begin{tabular}{ccc}
\hline No. & Lokasi AP & WVLAN \\
\hline 1. & Tower A & 348 \\
2. & Tower B & 356 \\
3. & Tower C & 364 \\
4. & Tower D & 372 \\
\hline
\end{tabular}

\section{Hasil pemetaan jaringan Binus Square}

Pemetaan jaringan dilakukan dengan meneliti langsung di tiap lorong tower A dan tower B Binus Square dengan software pemetaan jaringan, Ekahau Heatmapper. Melalui pemetaan diperoleh cakupan sinyal dari akses poin yang terlacak pada tiap lorong dan channel yang dikonfigurasi pada akses poinnya. Berikut terlampir beberapa gambar yang merupakan hasil pemetaan jaringan dari akses poin. Pemetaan dilakukan secara menyeluruh pada tiap lorong tower A dan B di Binus Square, namun di sini hanya ditampilkan beberapa saja.

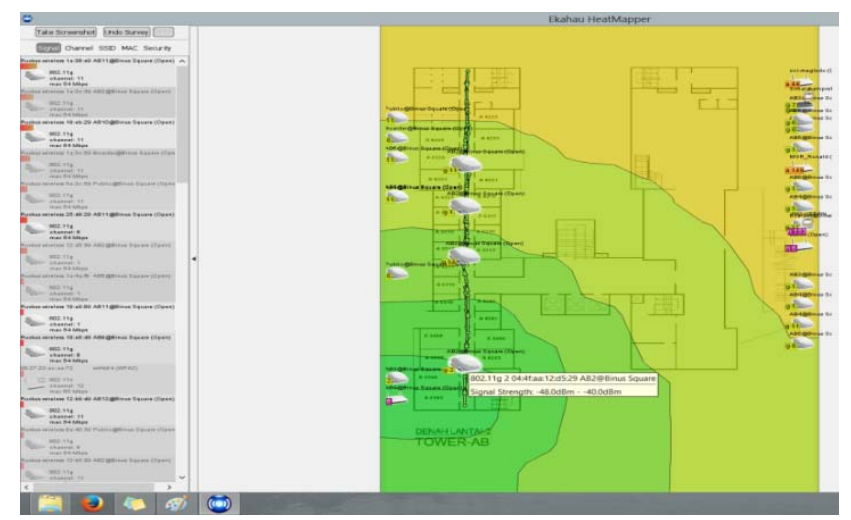

Gambar 15 Cakupan sinyal akses poin ke-1 lantai 2 Tower A 


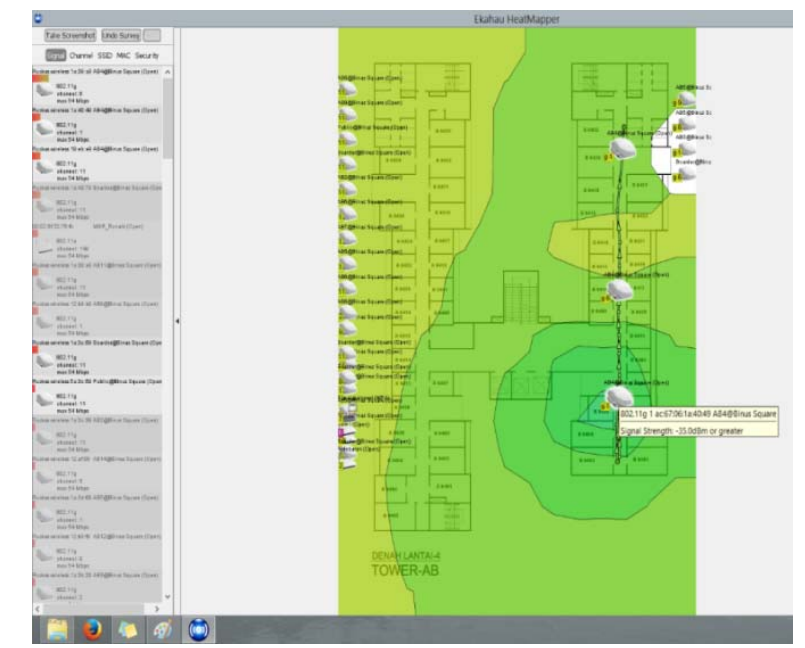

Gambar 16 Cakupan sinyal akses poin ke-1 lantai 4 Tower B

\section{Perancangan Topologi Jaringan Baru}

Berdasarkan pengamatan dan penelitian dimana tower A-B dan C-D yang terhubung dengan hanya satu server terlihat belum cukup maksimal dan diperlukan penambahan server lagi di mana tower pria (A-B) terhubung dengan satu server dan tower wanita (C-D) terhubung dengan server lainnya lagi dan masing-masing diatur dengan satu bandwidth management dan keduanya lalu dihubungkan dengan server farm. Hal ini diyakini akan meningkatkan performa jaringan Binus Square sehingga switch dan server yang dahulu tidak akan bekerja terlalu keras lagi sehingga lebih awet dan performa jaringan akan lebih baik.

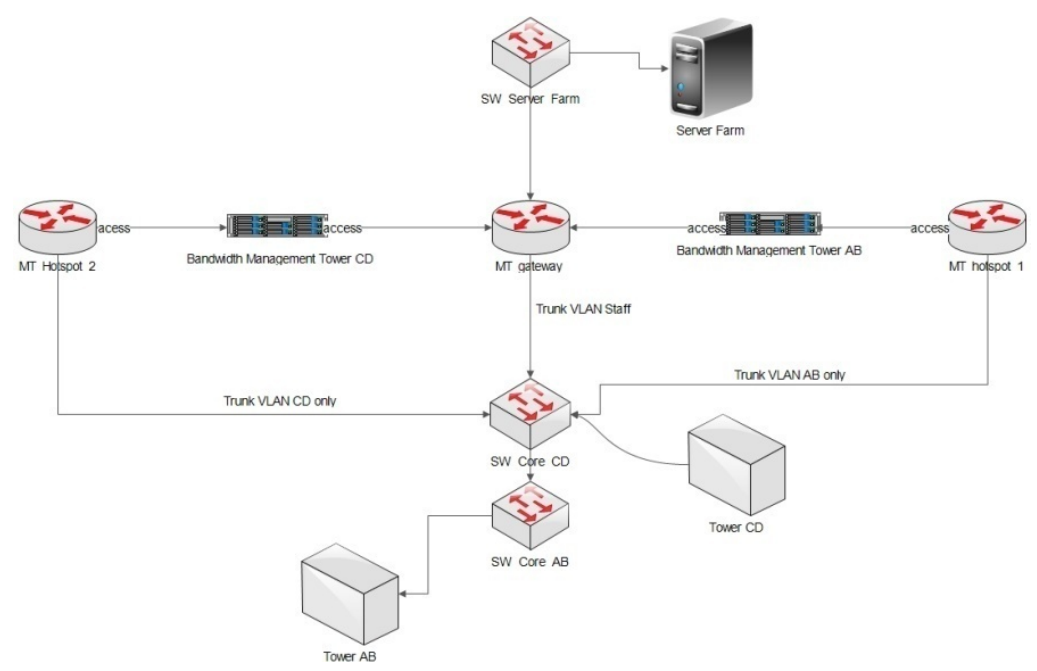

Gambar 17 Topologi Jaringan Baru Binus Square

\section{Analisa Jumlah User terhadap Ketersediaan Akses Poin}

Berdasarkan hasil pengamatan jumlah user yang paling banyak menggunakan jaringan nirkabel Binus Square tercatat sejumlah 817 user. Berdasarkan analisa jumlah akses poin di mana ratarata dalam satu lantai terdapat tiga akses poin, maka dapat ditentukan apakah akses poin yang ada mencukupi kebutuhan user atau apakah diperlukan penambahan akses poin. Tower A berjumlah 16 
lantai dengan total 48 akses poin. Tower B berjumlah 14 lantai dengan total 42 akses poin. Gabungan tower A dan tower B menghasilkan total 90 akses poin, 1 akses poin dapat digunakan maksimal 10 user maka maksimal user yang dapat tergabung dalam jaringan nirkabel Binus Square pada tower A dan B adalah 900 user. Maka berdasarkan pengamatan didapatkan bahwa jumlah akses poin masih memenuhi kebutuhan user dan tidak perlu dilakukan penambahan kecuali bila pihak Binus Square ingin memberikan hasil yang lebih optimal pada jaringan Binus Square.

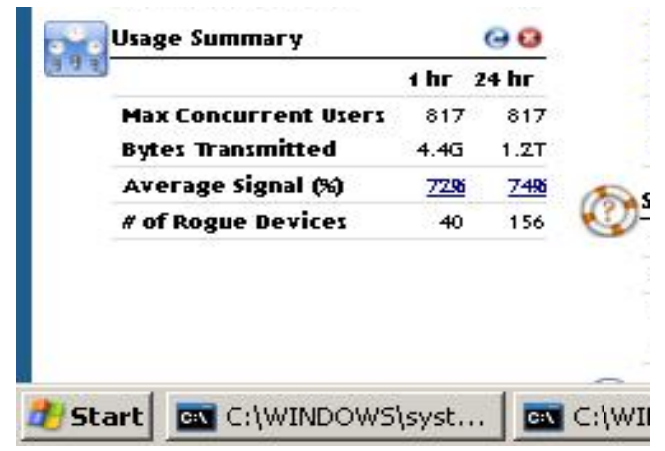

Gambar 18 Pengamatan jumlah user

\section{Hasil Pengamatan Roaming setelah Perubahan Konfigurasi Akses poin dan Topologi}

Gambar dibawah menunjukkan hasil pengamatan jumlah roaming yang terjadi dan ditampilkan melalui grafik batang. Pengukuran dilakukan pada tanggal 11 Desember 2013 sampai 13 Desember 2013 lalu dilanjutkan tanggal 18 Desember 2013 dan 8 Januari 2014 dengan 10 Januari 2014. Pengukuran dilanjutkan kembali pada Januari karena pada bulan Desember tanggal 20 sampai 6 Januari 2014 tidak ada kegiatan perkuliahan sehingga banyak penghuni yang juga tidak menempati Binus Square, yang mengakibatkan hasil pengamatan roaming kurang maksimal bila diteruskan pada tanggal 20 Desember keatas.

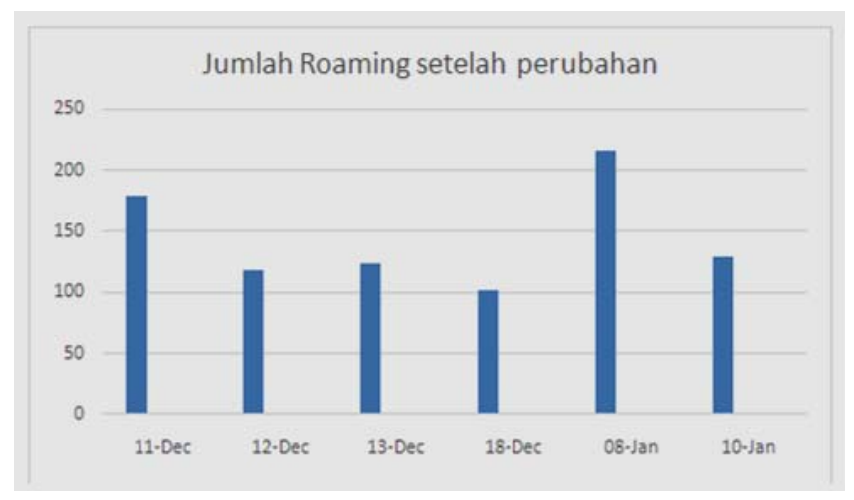

Gambar 19 Jumlah Roaming setelah perubahan

Pada hasil pengukuran ditemukan roaming hanya terjadi pada sama lantai dan sama tower sedangkan roaming berlainan lantai dan atau berlainan tower sudah tidak terjadi lagi, hal ini dikarenakan penyesuaian SSID dan channel pada jaringan topologi Binus Square. Pengukuran dilakukan pada jam 19.00 sampai 21.00. Jumlah roaming pada hasil pengukuran ini adalah 867 roaming. Hasil pengukuran menunjukan penurunan jumlah roaming yang siknifikan dibandingkan pengukuran sebelumnya (4169 roaming). 


\section{SIMPULAN}

Adapun simpulan yang dapat diambil dari hasil perancangan aplikasi yang sudah dibuat adalah: (1) Penurunan jumlah roaming membuktikan bahwa penelitian ini berhasil. (2) Lantai yang memiliki access point dengan jumlah empat unit access point per tower menunjukkan tingkat roaming yang rendah dan hampir tidak ada. (3) Penyesuaian channel masing-masing access point agar tidak bertabrakan dalam jarak yang dekat membuktikan dapat menurunkan tingkat roaming. (4) Penggantian SSID per lantai langsung bisa meniadakan roaming antar lantai. (5) Roaming yang paling sering terjadi adalah roaming sama lantai, sama tower. (6) Performa masing-masing akses poin dapat mempengaruhi kualitas overall sinyal akses poin dalam satu lantai.

\section{DAFTAR PUSTAKA}

Dhe, A. (2013). Ruckus Wireless. Diakses 5 Oktober 2013 dari http://www.skill.co.id/front/index.php/jakarta-products/325-ruckus

Kotz, D., Essien, K. (2005). Trace Collection. Analysis of a Campus-Wide Wireless Network. Diakses 10 Oktober 2013 dari http://www.cs.odu.edu/nadeem/classes/cs795-WNS-S13/papers/enter012.pdf

Mitchel, B. (2011). Bandwidth Diakses $6 \quad$ Oktober 2013 dari http://compnetworking.about.com/od/speedtests/g/bldef_bandwidth.htm

Priscaro, M. (2010). The Smart Wi-Fi Antenna Technology that Steers Signals to High-Quality Paths. Diakses 5 Oktober 2013 dari http://www.ruckuswireless.com/technology/beamflex

Priscaro, M. (2010). Ultra-fast and Reliable Smart Wi-Fi Access Points with Adaptive Antenna $\begin{array}{lllll}\text { Technology. } & \text { Diakses } & 5 & \text { Oktober } & 2013\end{array}$ http://www.ruckuswireless.com/products/zoneflex-indoor 